\title{
COMPARISON OF IMPLANT DENSITY IN THE MANAGEMENT OF LENKE 1B AND 1C ADOLESCENT IDIOPATHIC SCOLIOSIS
}

\section{COMPARAÇÃO DA DENSIDADE DO IMPLANTE NO TRATAMENTO DA ESCOLIOSE IDIOPÁTICA DO ADOLESCENTE LENKE 1B E 1C}

\author{
Bekir ERay Kilinc ${ }^{1}$, Dong Phuong Tran $^{1}$, Charles Johnston ${ }^{1}$
}

1. Texas Scottish Rite Hospital for Children, Dallas, TX, USA.

\section{ABSTRACT}

Objective: To compare radiographic and surgical outcomes of Lenke $1 \mathrm{~B}$ and $1 \mathrm{C}$ patterns. Methods: One hundred twenty patients with Lenke $1 \mathrm{~B}$ and $1 \mathrm{C}$ scoliosis were grouped according to implant density as follows: low density (LD) of $\leq 1.4$ and high density (HD) of $>1.4$. Matched subgroups (30 patients each) based on age, curve magnitude, and body mass index (BMI) were analyzed. Radiographic parameters were evaluated before operation, immediately after operation (ipo), and at 2 years' follow-up. SRS-30 was administered before operation and at 2 years' follow-up. Results: The major curves of the LD $(n=82)$ and HD groups $(n=38)$ were respectively $59.1^{\circ}$ and $65.6^{\circ}$ before operation $(p<.001), 26.3^{\circ}$ and $22.9^{\circ}$ ipo $(p=.05)$, and $29.9^{\circ}$ and $19.8^{\circ}$ at 2 years' follow-up $(p<.001)$. No significant differences in postoperative trunk shift and coronal balance were found ( $p=.69$ and $p=.74$, respectively). The HD group had higher blood loss ( $p=.02$ ), number of implants $(p<.001)$, levels fused $(p=.002)$, and surgical time $(p<$ .001). The HD group had a higher prevalence of hypokyphosis from before operation to follow-up $(p<.001)$. No significant differences were observed in the SRS- 30 scores before operation and at 2 years' follow-up. The matched groups had similar preoperative major curves $(p=.56)$, ages $(p=.75)$, and BMls $(p=.61)$. Significantly longer surgical time $(p=.009)$, higher density $(p<.001)$, and better correction $(p=.0001)$ were found in the HD group at 2 years' follow-up. No significant differences were found in the SRS-30 scores before operation and at 2 years' follow-up. Conclusion: LD constructs included fewer segments fused, lower intraoperative estimated surgical blood loss, and shorter operation time, and potentially decreasing complication risks due to fewer implants. Level of evidence III, Retrospective Cohort Study.

Keywords: Scoliosis. Lenke 1B. Lenke 1C. Adolescent idiopathic scoliosis. Screw instrumentation.

\section{RESUMO}

Objetivo: Comparar os desfechos radiográficos e cirúrgicos da escoliose Lenke 1B e 1C. Métodos: Cento e vinte pacientes com escoliose Lenke 1B e 1C foram agrupados de acordo com a densidade do implante, como segue: baixa densidade (BD) de $\leq$ 1,4 e alta densidade $(A D)$ de $>1,4$. Foram analisados os grupos pareados (30 pacientes cada) com base na idade, magnitude da curva e índice de massa corporal (IMC). Os parâmetros radiográficos foram avaliados antes da cirurgia, no pós-operatório imediato (POI) e no acompanhamento de dois anos. O questionário SRS-30 foi administrado antes da cirurgia e no acompanhamento de dois anos. Resultados: As principais curvas dos grupos $B D(n=82)$ e $A D(n$ $=38$ ) foram respectivamente $59,1^{\circ}$ e $65,6^{\circ}$ antes da operação ( $p$ $<0,001), 26,3^{\circ}$ e $22,9^{\circ}$ no $P O I(p=0,05)$ e $29,9^{\circ}$ e $19,8^{\circ}$ aos 2 anos de acompanhamento $(p<0,001)$. Não foram encontradas diferenças significantes no desvio do tronco e no balanço coronal no pós-operatório ( $p=0,69$ e $p=0,74$, respectivamente). O grupo $A D$ teve mais perda sanguínea $(p=0,02)$, número de implantes $(p<$ $0,001)$, níveis de fusão $(p=0,002)$ e tempo de cirurgia $(p<0,001)$. O grupo AD teve maior prevalência de hipocifose do período anterior à cirurgia até $o$ acompanhamento $(p<0,001)$. Não houve diferenças significantes nas pontuações do SRS-30 antes da operação e aos 2 anos de acompanhamento. No pré-operatório, os grupos pareados tinham curvas principais $(p=0,56)$, idade $(p=0,75)$ e IMC $(p=0,61)$ semelhantes. Constatou-se tempo cirúrgico expressivamente maior $(p=0,009)$, maior densidade $(p<0,001)$ e melhor correção $(p=$ $0,0001)$ no grupo $A D$ aos 2 anos de acompanhamento. Não foram encontradas diferenças significantes nas pontuações do SRS-30 antes da cirurgia e no acompanhamento de 2 anos. Conclusão: As estruturas de BD incluíram menos segmentos fundidos, menor perda de sangue intraoperatória estimada, menor tempo de cirurgia e menos risco de complicações, com possibilidade de redução, por causa do menor número de implantes. Nível de evidência III, Estudo retrospectivo de coorte.

Descritores: Escoliose. Parafusos ósseos.

Citation: Kilinc BE, Tran DP, Johnston C. Comparison of implant density in the management of lenke 1B and 1C adolescent idiopathic scoliosis. Acta Ortop Bras. [online]. 2019;27(1):33-7. Available from URL: http://www.scielo.br/aob.

All authors declare no potential conflict of interest related to this article.

Study was conducted at the Texas Scottish Rite Hospital for Children, Dallas, TX, USA.

Correspondence: Bekir Eray Kilinc. 2222 Welborn St, Dallas, TX, USA. 75219. dreraykilinc@gmail.com 


\section{INTRODUCTION}

Adolescent idiopathic scoliosis (AIS) is a 3-dimensional deformity with a coronal, sagittal, and rotational deformity of the spine that arises in otherwise healthy children. Curves greater than $50^{\circ}$ at skeletal maturity may progress over time, resulting in worsening deformity and, in the case of thoracic curves, subtle pulmonary.1,2 Due to the possibility of curve progression, surgical treatment is typically recommended for deformity greater than $50^{\circ}$, particularly in the skeletally immature patient..$^{3,4}$ Pedicle screw instrumentation is currently the preferred method to achieve optimal correction of deformity in AIS. ${ }^{5}$ However, preferred instrumentation montage remains controversial because the optimum number and configuration of implants has not been determined. ${ }^{6-8}$

Implant density is defined as the number of implants per level fused. A study group report showed that implant densities varied from 1.04 to 2.0 screws per level, yet the mean percentage of major curve correction was only changed from $64 \%$ to $70 \% .{ }^{9}$

For the most common type of AIS, the Lenke 1 thoracic deformity, high density (HD) constructs are often utilized for gaining significant correction. ${ }^{8,10,11}$ For $1 \mathrm{~A}$ AIS curves, maximum correction has essentially no risk of coronal decompensation postoperatively. However, for $1 \mathrm{~B}$ and especially $1 \mathrm{C}$ patterns, maximum correction enhances the risk of coronal imbalance, and therefore more modest correction to maintain overall trunk balance is usually recommended. Using a lower density (LD) construct with fewer anchor points is one possible technique to counter the tendency for maximum correction with a HD construct.

The purpose of this study was to compare outcomes in Lenke 1B and $1 \mathrm{C}$ AIS patients treated by either HD or LD constructs. Our hypothesis was that LD constructs would show no difference in radiographic or surgical outcomes compared to HD constructs, and by virtue of using fewer implants, would decrease operative time and blood loss, potentially reducing risk of complications and costs.

\section{MATERIALS AND METHODS}

We reviewed a single institution retrospective database of surgically treated AIS patients with Lenke $1 \mathrm{~B}$ and $1 \mathrm{C}$ curve patterns between 2002 and 2013. Full approval University of Texas Southwestern IRB. Inclusion criteria were complete radiographic and clinical data preoperatively, immediately after surgery, and at 2-year follow-up, and perioperative surgical data. Outcome measures include radiographic parameters, surgical data, and patient-reported SRS-30 data at follow up. The study cohort was divided into two groups based on implant density. The low density (LD) group was defined as implants per level less than or equal to 1.4 (Figure 1,2) and higher density (HD) was defined as greater than 1.4 per level fused (Figure 3, 4). At least $75 \%$ of the implants had to be pedicle screws for both cohorts. The relationship between implant density and clinical, radiographic, and surgical variables were investigated. We also analyzed Risser grade data based on the two density groups to determine if Risser grade has an effect on density. Separately, we compared matched subgroups based on preoperative age, curve magnitude, and BMI, created with 30 patients from LD group and 30 from HD group to analyze the relationship between implant density and surgical outcomes.

Statistical analysis using the Mann-Whitney test based on nonparametric measures was performed on the entire study group and the matched subgroups.

\section{RESULTS}

One hundred and twenty AIS patients met the inclusion criteria, with 58 Lenke $1 \mathrm{C}$ and 62 Lenke 1B curves. There were 107 female and 13 male patients. The mean age at the surgery was 14.3 years

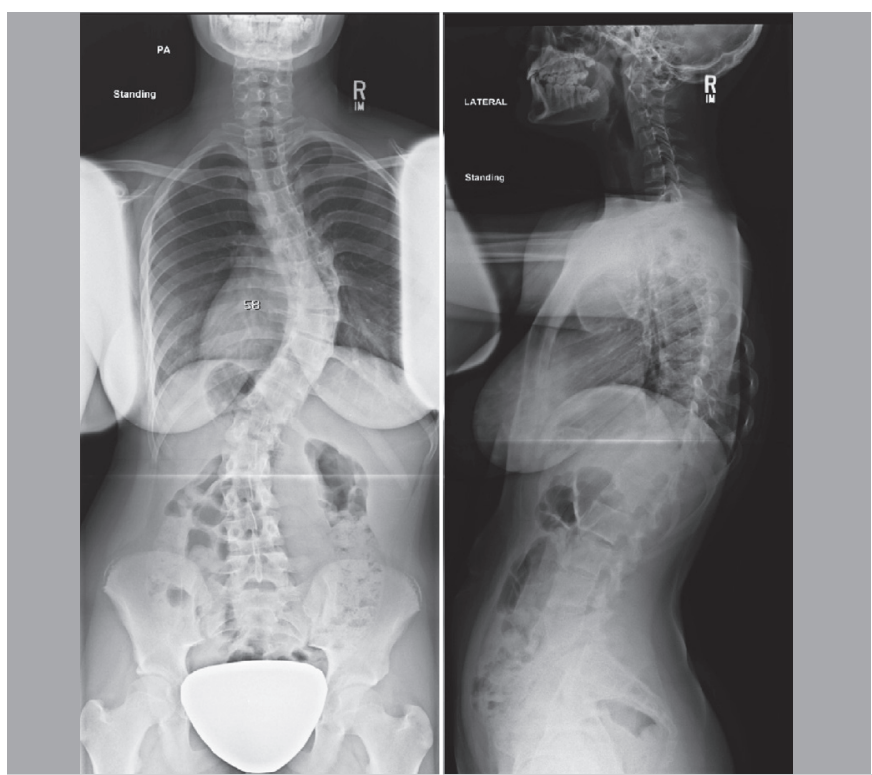

Figure 1. Coronal and sagittal radiographs of a 14 year-old female with $58^{\circ}$ preoperatively.
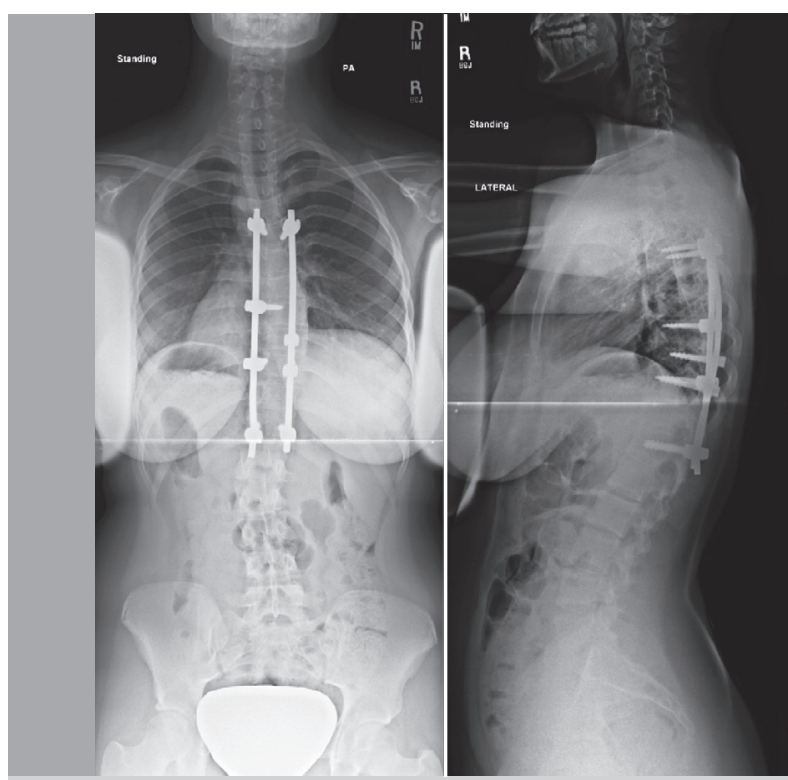

Figure 2. Two-year postoperative radiographs of patient treated with PSF with low implant density, 1.0.

(range 9.8-19.1 years). The preoperative mean main thoracic Cobb angle measured $61.2^{\circ}$, corrected to $25.3^{\circ}$ postoperatively, and was $28.5^{\circ}$ at 2-year follow-up. Overall mean implant density was 1.3 with an average of 9.6 levels fused.

There were 82 patients in the LD group and 38 in the HD group. The mean preoperative major curves of LD and HD groups were $59.1^{\circ}$ and $65.6^{\circ}(p<0.001) ; 26.3^{\circ} \mathrm{vs} .22 .9^{\circ}(p=0.05)$ at immediately postoperative, and $29.9^{\circ}$ vs. $19.8^{\circ}(p<0.001)$ at 2-year follow up. The HD group had significantly higher major coronal Cobb angle and more correction in major coronal Cobb angle $(p<0.001)$. The HD group had a larger preoperative trunk shift $(p=0.02)$ than the LD group, but by 2 -year follow up, the trunk imbalance difference had resolved (Table 1). There were a larger number of implants per level in the HD group (1.6 \pm 0.1 vs $1.1 \pm 0.2 ; p<0.0001)$, and the HD group required one additional level fused (10.2 \pm 1.6 vs. $9.3 \pm 1.3, p=0.002$ ) (Table 2). 

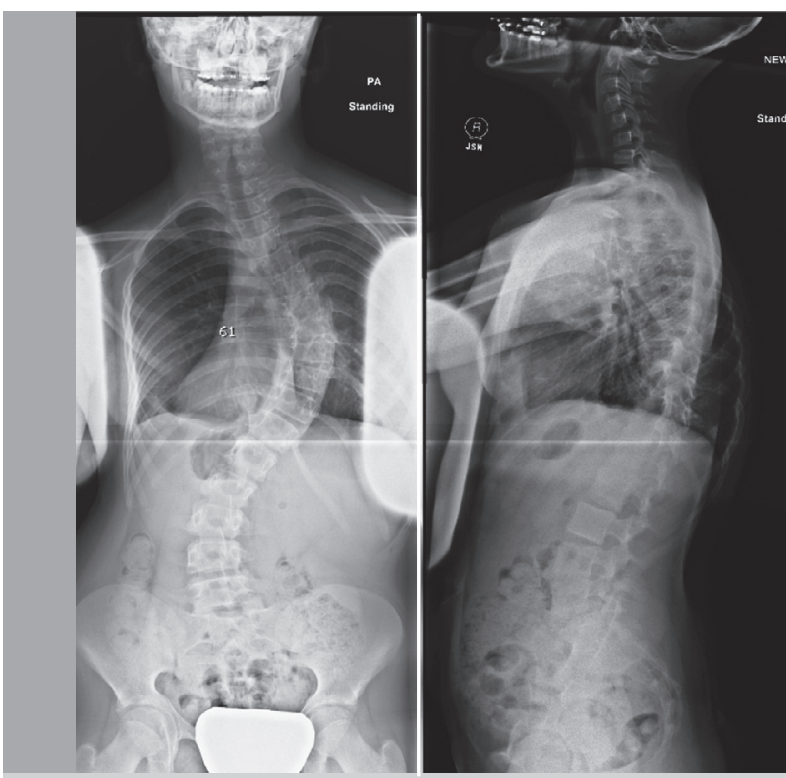

Figure 3. Coronal and sagittal radiographs of a 14 year-old female with $61^{\circ}$ preoperatively.

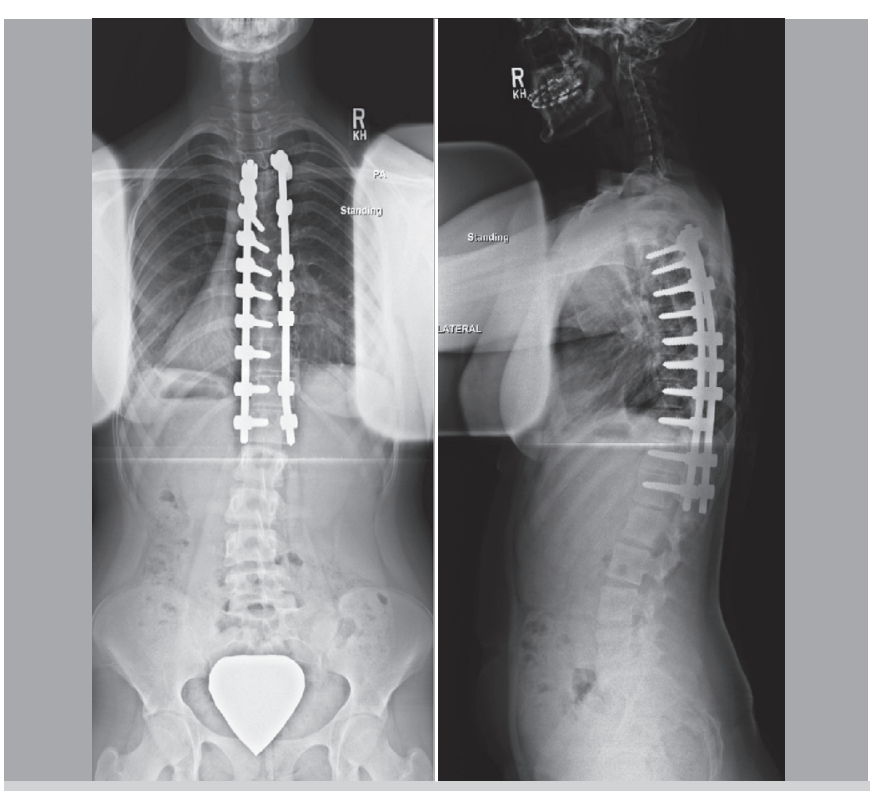

Figure 4. Two-year postoperative radiographs of patient treated with PSF with higher implant density, 1.7.

In the sagittal plane, the HD group had a larger preoperative mean T2-T12 kyphosis $(p<0.01)$ and realized greater decrease in kyphosis $(p<0.001)$ than the LD group. Consequently there was no difference at follow up in sagittal plane alignment between the groups. There was no difference between LD and HD groups in correction and maintenance of correction of trunk shift and coronal balance $(p=0.69, p=0.74$ and $p=0.83, p=0.57$ ) (Table 1).

There was no difference in any of the 5 categories of SRS-30 scores at preop and 2 year follow up (Table 3 ). There was no correlation between implant density and BMI $(p=0.72)$ (Table 4). However, the $\mathrm{HD}$ group required significantly longer operative time than the LD group (294 vs 251 minutes, $p<0.001)$ and had greater intraoperative blood loss (641 vs. $496 \mathrm{~cm}^{3}, \mathrm{p}=0.02$ ) (Table 2).

The matched subgroups had similar preoperative curve magnitude $(p=0.55)$, age $(p=0.75)$, BMl $(p=0.61)$ and level fused $(p=0.09)$

\begin{tabular}{c|c|c|c}
\multicolumn{5}{c}{ Table 1. Study Cohort Radiographic Outcomes } \\
\hline Preop Major Curve & LD & HD & $\mathbf{p}$ \\
\hline 2 Year Major Curve & $\begin{array}{c}59.1 \pm 6 \\
(49,77)\end{array}$ & $\begin{array}{c}29.9 \pm 11.5 \\
(48,92)\end{array}$ & $<0.001$ \\
\hline Major curve: preop \&immediate & $\begin{array}{c}-32.8 \pm 9.8) \\
(-60,-9) \\
(-44,44)\end{array}$ & $\begin{array}{c}-42.6 \pm 12.3 \\
(-68,-15)\end{array}$ & $<0.001$ \\
\hline Preop Coronal Balance & $\begin{array}{c}10.7 \pm 9.5 \\
(0,41)\end{array}$ & $\begin{array}{c}12.5 \pm 10.5 \\
(0,40)\end{array}$ & 0.42 \\
\hline 2-Year Coronal Balance & $\begin{array}{c}13.3 \pm 11 \\
(0,50)\end{array}$ & $\begin{array}{c}12.2 \pm 10.1 \\
(0,38)\end{array}$ & 0.72 \\
\hline Preop Trunk Shift & $\begin{array}{c}15.5 \pm 10.2 \\
(0,39)\end{array}$ & $\begin{array}{c}20.7 \pm 12.1 \\
(1,47)\end{array}$ & 0.02 \\
\hline 2-Year Trunk Shift & $\begin{array}{c}8.9 \pm 7.8 \\
(0,30)\end{array}$ & $\begin{array}{c}9.6 \pm 8.3 \\
(0,28)\end{array}$ & 0.84 \\
\hline Preop Kyphosis & $\begin{array}{c}27.2 \pm 13.9 \\
(1,65)\end{array}$ & $\begin{array}{c}34.7 \pm 13.6 \\
(7,61)\end{array}$ & 0.007 \\
\hline 2-Year Kyphosis & $\begin{array}{c}34 \pm 11.5 \\
(7,60)\end{array}$ & $\begin{array}{c}33.3 \pm 12.5 \\
(5,53)\end{array}$ & 0.93 \\
\hline$\Delta$ Kyphosis: preop \& immediate & $\begin{array}{c}3.3 \pm 11 \\
(-24,24)\end{array}$ & $\begin{array}{c}-5.6 \pm 10.5 \\
(-27,11)\end{array}$ & $<0.001$ \\
\hline & & &
\end{tabular}

Table 2. Study Cohort Surgical Outcomes

\begin{tabular}{c|c|c|c}
\hline & LD & HD & $\mathbf{p}$ \\
\hline Level fused & $9.3 \pm 1.3$ & $10.2 \pm 1.6$ & 0.002 \\
\hline Total Implants & $10.1 \pm 2.2$ & $16.4 \pm 2.4$ & $<0.001$ \\
\hline Implant Density & $1.1 \pm 0.2$ & $1.6 \pm 0.1$ & $<0.001$ \\
\hline EBL & $496.4 \pm 309.1$ & $640.9 \pm 381.1$ & 0.02 \\
\hline Operative Time & $251 \pm 68.1$ & $293.6 \pm 73.1$ & $<0.001$ \\
\hline
\end{tabular}

(Table 4). The HD group had significantly higher overall number of implants per level (1.6 \pm 0.1 vs $1.1 \pm 0.2 ; p<0.0001)$ (Table $5)$, and achieved greater correction at 2 years $\left(20.7^{\circ}\right.$ vs. $31^{\circ}$, $p<0.001)$ compared to the matched LD group. HD group were more hypokyphosis from preop to immediate follow-up ( $p=0.02)$. There was no statistically significant difference between 2 groups' preoperative or 2 year coronal balance or trunk shift (Table 6). However there was a significant difference between operative time (HD 292 minutes vs. LD 252 minutes, $p=0.008$ ). HD group had higher mean blood loss than LD group, although this difference was not significant $(p=0.22)$ (Table 5$)$. There was no difference in SRS-30 total scores at preop and 2 year follow-up and again Risser grade had no effect on density.

\section{DISCUSSION}

Lenke Type 1 thoracic scoliosis is the most common type of AIS deformity. To correct the deformity and to recover the trunk balance is the main goal in the surgical management of AIS patients. ${ }^{12}$ Additionally, significant correction has been a desired goal since the introduction of higher density constructs in the 1980's. Several studies confirm that increased implant density of pedicle screw instrumentation is correlated with increased coronal correction. 8,10,11 On the other hand studies of lower-density fixation, such as skipped pedicle screw placement constructs, report this to be an efficient and safe method in management of AIS..$^{13-17}$

Radiologic parameters after AIS surgical treatment do not correlate with clinical outcomes as evaluated by SRS 30 questionnaire scores, confirming that the need for greatest deformity correction is perhaps unfounded. In this study, patients treated with HD instrumentation had larger preoperative 
Table 3. SRS scores: Preop vs 2 year follow-up in study cohort and matched groups.

\begin{tabular}{|c|c|c|c|c|c|c|c|c|c|c|c|c|}
\hline & \multicolumn{6}{|c|}{ Study cohort } & \multicolumn{6}{|c|}{ Matched group } \\
\hline & \multicolumn{3}{|c|}{ Preop } & \multicolumn{3}{|c|}{2 Year follow-up } & \multicolumn{3}{|c|}{ Preop } & \multicolumn{3}{|c|}{2 Year follow-up } \\
\hline & LD & HD & $\mathbf{P}$ & LD & HD & $\mathbf{P}$ & LD & HD & $\mathbf{P}$ & LD & HD & $\mathbf{P}$ \\
\hline Pain & $4 \pm 0.6$ & $4.1 \pm 0.6$ & 0.38 & $4.2 \pm 0.7$ & $4.3 \pm 0.5$ & 0.41 & $3.9 \pm 0.6$ & $4.1 \pm 0.5$ & 0.25 & $4.1 \pm 0.8$ & $4.4 \pm 0.4$ & 0.46 \\
\hline Appearance & $3.3 \pm 0.6$ & $3.2 \pm 0.5$ & 0.44 & $4 \pm 0.7$ & $4.3 \pm 0.5$ & 0.16 & $3.2 \pm 0.7$ & $3.3 \pm 0.5$ & 0.83 & $4 \pm 0.7$ & $4.3 \pm 0.5$ & 0.31 \\
\hline Activity & $4.2 \pm 0.5$ & $4.1 \pm 0.6$ & 0.83 & $4.2 \pm 0.5$ & $4.3 \pm 0.5$ & 0.16 & $4.2 \pm 0.6$ & $4.2 \pm 0.5$ & 0.98 & $4.1 \pm 0.6$ & $4.4 \pm 0.4$ & 0.06 \\
\hline Mental & $4.1 \pm 0.6$ & $3.9 \pm 0.7$ & 0.57 & $4.2 \pm 0.6$ & $4.2 \pm 0.6$ & 0.65 & $3.9 \pm 0.6$ & $4.1 \pm 0.5$ & 0.37 & $4.2 \pm 0.6$ & $4.2 \pm 0.6$ & 0.73 \\
\hline Satisfaction & $3.6 \pm 0.9$ & $3.6 \pm 0.9$ & 0.8 & $4.4 \pm 0.7$ & $4.6 \pm 0.5$ & 0.1 & $4.1 \pm 0.8$ & $3.6 \pm 0.8$ & 0.44 & $4.5 \pm 0.7$ & $4.6 \pm 0.5$ & 0.65 \\
\hline Total Score & $3.9 \pm 0.4$ & $3.8 \pm 0.4$ & 0.73 & $4.1 \pm 0.3$ & $4.3 \pm 0.3$ & 0.16 & $3.8 \pm 0.5$ & $3.9 \pm 0.3$ & 0.75 & $4.1 \pm 0.3$ & $4.3 \pm 0.2$ & 0.1 \\
\hline
\end{tabular}

Table 4. Preop clinical: Study cohort and matched group.

\begin{tabular}{c|c|c|c|c|c|c}
\hline & \multicolumn{3}{|c|}{ Study cohort } & \multicolumn{3}{c}{ Matched group } \\
\hline & LD & HD & p value & LD & HD & p value \\
\hline Age at surgery & $14.4 \pm 2$ & $14.1 \pm 2$ & 0.47 & $14.2 \pm 2.2$ & $14.3 \pm 2.1$ & 0.75 \\
\hline Height & $156.8 \pm 8.4$ & $157.3 \pm 8.6$ & 0.70 & $154.4 \pm 8.7$ & $157.6 \pm 8.7$ & 0.17 \\
\hline Weight & $54.6 \pm 52.5$ & $54.6 \pm 16.7$ & 0.82 & $54.1 \pm 14.8$ & $55.6 \pm 18.1$ & 0.73 \\
\hline BMl & $22.1 \pm 20.7$ & $21.9 \pm 5.2$ & 0.48 & $22.5 \pm 4.9$ & $22.1 \pm 5.7$ & 0.61 \\
\hline $\begin{array}{c}\text { Preop, major } \\
\text { curve }\end{array}$ & $59.1 \pm 6$ & $65.6 \pm 10.5$ & 0.00 & $62.7 \pm 7$ & $61.7 \pm 7.6$ & 0.55 \\
\hline Total Score & $3.9 \pm 0.4$ & $3.8 \pm 0.4$ & 0.73 & $4.1 \pm 0.3$ & $4.3 \pm 0.3$ & 0.16 \\
\hline
\end{tabular}

Table 5. Matched Groups Surgical Outcomes.

\begin{tabular}{c|c|c|c}
\hline & LD & HD & P \\
\hline Level fused & $9.4 \pm 1.3$ & $10 \pm 1.5$ & 0.09 \\
\hline Total Implants & $10.3 \pm 2.3$ & $16.1 \pm 2.5$ & $<0.001$ \\
\hline Implant Density & $1.1 \pm 0.2$ & $1.6 \pm 0.1$ & $<0.001$ \\
\hline EBL & $486.7 \pm 216.2$ & $642.3 \pm 420.8$ & 0.23 \\
\hline Operative time & $251.7 \pm 82.5$ & $292.5 \pm 73.6$ & 0.008 \\
\hline
\end{tabular}

Table 6. Matched Group Radiographic Outcomes.

\begin{tabular}{|c|c|c|c|}
\hline & LD & $H D$ & $p$ \\
\hline Preop Major Curve & $\begin{array}{l}62.7 \pm 7 \\
(51,77)\end{array}$ & $\begin{array}{c}61.7 \pm 7.6 \\
(48,75)\end{array}$ & 0.56 \\
\hline 2 Year Major Curve & $\begin{array}{c}31 \pm 15.7 \\
(-20,53)\end{array}$ & $\begin{array}{c}20.7 \pm 11.8 \\
(-19,39)\end{array}$ & $<0.001$ \\
\hline $\begin{array}{c}\Delta \text { Major curve: } \\
\text { preop \&immediate }\end{array}$ & $\begin{array}{c}-32.8 \pm 11.1 \\
(-60,-9)\end{array}$ & $\begin{array}{c}-39.2 \pm 10.9 \\
(-64,-15)\end{array}$ & 0.02 \\
\hline Preop Coronal Balance & $\begin{array}{c}9.9 \pm 7.4 \\
(0,24)\end{array}$ & $\begin{array}{c}12.7 \pm 11.3 \\
(0,40)\end{array}$ & 0.52 \\
\hline 2-Year Coronal Balance & $\begin{array}{c}11.9 \pm 9.6 \\
(0,38)\end{array}$ & $\begin{array}{c}13.5 \pm 11 \\
(0,38)\end{array}$ & 0.65 \\
\hline Preop Trunk Shift & $\begin{array}{c}16.2 \pm 9.6 \\
(2,37)\end{array}$ & $\begin{array}{c}18.8 \pm 11.4 \\
(1,47)\end{array}$ & 0.37 \\
\hline 2-Year Trunk Shift & $\begin{array}{c}9.9 \pm 7.3 \\
(0,30)\end{array}$ & $\begin{array}{c}10.7 \pm 8.6 \\
(0,28)\end{array}$ & 0.87 \\
\hline Preop Kyphosis & $\begin{array}{c}26.5 \pm 13.9 \\
(1,57)\end{array}$ & $\begin{array}{c}32.7 \pm 13.3 \\
(7,56)\end{array}$ & 0.07 \\
\hline 2-Year Kyphosis & $\begin{array}{c}33.6 \pm 13.1 \\
(8,60)\end{array}$ & $\begin{array}{c}32.7 \pm 12.9 \\
(5,53)\end{array}$ & 0.89 \\
\hline $\begin{array}{c}\Delta \text { Kyphosis: preop } \\
\text { \& immediate }\end{array}$ & $\begin{array}{c}2.3 \pm 10.2 \\
(-24,24)\end{array}$ & $\begin{array}{c}-4.3 \pm 10.3 \\
(-27,11)\end{array}$ & 0.02 \\
\hline
\end{tabular}

curve magnitudes and achieved more coronal correction and sagittal plane change, consistent with current HD practice, but two year postoperative SRS-30 scores not surprisingly did not demonstrate any differences between LD and HD groups. Increasing implant density in our study had no effect on the SRS-30 outcomes, including appearance and trunk balance parameters. ${ }^{18}$

Thoracic hypokyphosis (THK) is a main feature of the 3-dimensional deformity typical of Lenke 1 AIS patients. ${ }^{19,20}$ THK can be exacerbated with further flattening of thoracic contour with pedicle screw instrumentation, ${ }^{21,22}$ although the effect of implant density on sagittal contour correction is inconsistent.11,13 In our study, correcting coronal deformity with HD implant instrumentation generated a lordotic change in sagittal contour at immediate and 2 year follow-up measured from T2-T12, although the absolute thoracic kyphosis at 2-year follow up was within normal limits in the entire cohort as well as the subgroups. This sagittal plane alteration illustrates a commonly-noted effect of greater implant density, an inverse relationship between thoracic curve correction in the coronal and the flattening of the sagittal plane. The effect of marked THK on the respiratory function in AIS has been previously documented., ${ }^{1,2}$

It is generally accepted that increased blood loss and allogeneic transfusion are associated with increased surgical complications. There is also conflicting literature regarding the contributing factors toward increased intraoperative blood loss in the management of pediatric spinal deformity. ${ }^{23-25}$ Increased blood loss is frequently associated with larger preoperative Cobb angles, longer fusion constructs, and the addition of osteotomies. ${ }^{23,25-27}$ Chang et al. suggested that the use of fewer screws can reduce bleeding and shorten the operative time. ${ }^{21}$ We have shown that LD implant instrumentation achieved similar outcomes, as judged by SRS-30 scores (Table 4), as HD constructs, with significantly reduced blood loss and shorter operative time. An additional theoretical advantage of an LD construct is related to the fewer number of pedicle screws to be inserted. Malpositioned screws have been implicated in vascular and neurologic injuries, with up to $1.8-5.1 \%$ of screws being malpositioned in pediatric deformity cases. ${ }^{28}$ Assuming 10 spinal levels are fused with two screws placed per level, this potentially represents one malpositioned screw per patient.29 While the clinical significance of asymptomatic malpositioned implants remains unknown, reducing the number of implants used decreases the amount of intraoperative radiation for screw placement, and theoretically decreases the potential for malpositioned implants, and thus the potential for revision surgery to correct malpositioning as well as decreasing the risk of vascular or neurologic injury. Finally, although not specifically evaluated in this study, the use of fewer implants can also save cost of surgical management. 
In conclusion, we have demonstrated in this single-institution comparison of Lenke $1 \mathrm{~B}$ and $1 \mathrm{C}$ curve patterns treated by either LD or HD constructs that, while the correction achieved in the HD group is greater than that for the LD group, the patient-derived outcomes at 2 year follow up as judged by the SRS-30 scores are no different. Advantages of the LD constructs included fewer segments fused, lower intraoperative blood loss and less operative time, and potentially decreasing complication risks due to fewer implants. Given the equivalent clinical outcomes, a reduction in the number of pedicle screws used for spinal fusion would increase patient safety and surgical efficiency. LD instrumentation was successful in the treatment of AIS with Lenke $1 \mathrm{~B}$ and $1 \mathrm{C}$ patients with satisfactory correction of coronal and sagittal deformity while reducing blood loss and operative time.

AUTHORS' CONTRIBUTIONS: Each author made significant individual contributions to this manuscript. BEK (0000-0003-1229-9815)*: data collection, drafting and revision of the manuscript. DT (0000-0002-8656-3458** data collection, and CJ (0000-0001-7178-1981)* performed the surgeries and revision *ORCID (Open Researcher and Contributor ID).

\section{REFERENCES}

1. Johnston CE, Richards BS, Sucato DJ, Bridwell KH, Lenke LG, Erickson M Correlation of preoperative deformity magnitude and pulmonary function tests in adolescent idiopathic scoliosis. Spine (Phila Pa 1976). 2011;36(14):1096-102.

2. Newton PO, Faro FD, Gallogly S, Betz RR, Lenke LG, Lowe TG. Results of preoperative pulmonary function testing of adolescents with idiopathic scoliosis. A study of six hundred thirty-one patients. J Bone Joint Surg Am. 2005;87(9):1937-46.

3. Cuartas E, Rasouli A, O'Brien M, Shufflebarger HL. Use of all-pedicle-screw constructs in the treatment of adolescent idiopathic scoliosis. J Am Acad Orthop Surg. 2009;17(9):550-61.

4. Bridwell KH. Surgical treatment of idiopathic adolescent scoliosis. Spine (Phila Pa 1976). 1999;24(24):2607-16.

5. Kim YJ, Lenke LG, Kim J, Bridwell KH, Cho SK, Cheh G, et al. Comparative analysis of pedicle screw versus hybrid instrumentation in posterior spinal fusion of adolescent idiopathic scoliosis. Spine (Phila Pa 1976). 2006;31(3):291-8.

6. Wang X, Aubin CE, Larson AN, Labelle H, Parent S. Biomechanical analysis of pedicle screw density in spinal instrumentation for scoliosis treatment: first results. Stud Health Technol Inform. 2012;176:303-6.

7. Belmont PJ Jr, Klemme WR, Robinson M, Polly DW Jr. Accuracy of thoracic pedicle screws in patients with and without coronal plane spinal deformities. Spine (Phila Pa 1976). 2002;27(14):1558-66.

8. Sanders JO, Diab M, Richards SB, Lenke LG, Johnston CE, Emans JB, et al Fixation points within the main thoracic curve: does more instrumentation produce greater curve correction and improved results? Spine (Phila Pa 1976). 2011;36:E1402-6.

9. Larson AN, Aubin CE, Polly DW Jr, Ledonio CG, Lonner BS, Shah SA, et al. Are More Screws Better? A Systematic Review of Anchor Density and Curve Correction in Adolescent Idiopathic Scoliosis. Spine Deform. 2013;1(4):237-47.

10. Clements DH, Betz RR, Newton PO, Rohmiller M, Marks MC, Bastrom T. Correlation of scoliosis curve correction with the number and type of fixation anchors. Spine (Phila Pa 1976). 2009;34(20):2147-50.

11. Quan GM, Gibson MJ. Correction of main thoracic adolescent idiopathic scoliosis using pedicle screw instrumentation: does higher implant density improve correction? Spine (Phila Pa 1976). 2010;35(5):562-7.

12. Weinstein SL, Dolan LA, Cheng JC, Danielsson A, Morcuende JA. Adolescent idiopathic scoliosis. Lancet. 2008;371(9623):1527-37.

13. Bharucha NJ, Lonner BS, Auerbach JD, Kean KE, Trobisch PD. Low-density versus high-density thoracic pedicle screw constructs in adolescent idiopathic scoliosis: do more screws lead to a better outcome? Spine J. 2013;13(4):375-81.

14. Chen J, Yang C, Ran B, Wang Y, Wang C, Zhu X, et al. Correction of Lenke 5 adolescent idiopathic scoliosis using pedicle screw instrumentation: does implant density influence the correction? Spine (Phila Pa 1976). 2013;38(15):E946-51.

15. Hwang CJ, Lee CK, Chang BS, Kim MS, Yeom JS, Choi JM. Minimum 5-year follow-up results of skipped pedicle screw fixation for flexible idiopathic scoliosis. J Neurosurg Spine. 2011;15(2):146-50.

16. Min K, Sdzuy C, Farshad M. Posterior correction of thoracic adolescent idiopathic scoliosis with pedicle screw instrumentation: results of 48 patients with minimal 10-year follow-up. Eur Spine J. 2013;22(2):345-54.

17. Li J, Cheung KM, Samartzis D, Ganal-Antonio AKB, Zhu X, Li M, et al. Key -vertebral screws strategy for main thoracic curve correction in patients with adolescent idiopathic scoliosis. Clin Spine Surg. 2016 Oct;29(8):E434-41.

18. Weinstein SL, Dolan LA, Spratt KF, Peterson KK, Spoonamore MJ, Ponseti IV. Health and function of patients with untreated idiopathic scoliosis: a 50-year natural history study. JAMA. 2003;289(5):559-67.

19. Schlösser TP, Shah SA, Reichard SJ, Rogers K, Vincken KL, Castelein RM. Differences in early sagittal plane alignment between thoracic and lumbar adolescent idiopathic scoliosis. Spine J. 2014;14(2):282-90.

20. Yong Q, Zhen L, Zezhang Z, Bangping Q, Feng Z, Tao W, et al. Comparison of sagittal spinopelvic alignment in Chinese adolescents with and without idiopathic thoracic scoliosis. Spine (Phila Pa 1976). 2012;37(12):E714-20.

21. Vora V, Crawford A, Babekhir N, Boachie-Adjei O, Lenke L, Peskin M, et al. A pedicle screw construct gives an enhanced posterior correction of adolescent idiopathic scoliosis when compared with other constructs: myth or reality. Spine (Phila Pa 1976). 2007;32(17):1869-74.

22. Lehman RA Jr, Lenke LG, Keeler KA, Kim YJ, Buchowski JM, Cheh G, et al. Operative treatment of adolescent idiopathic scoliosis with posterior pedicle screw-only constructs: minimum three year follow-up of one hundred fourteen cases. Spine (Phila Pa 1976). 2008;33(14):1598-604.

23. Hassan N, Halanski M, Wincek J, Reischman D, Sanfilippo D, Rajasekaran S, et al. Blood management in pediatric spinal deformity surgery: Review of a 2-year experience. Transfusion. 2011;51(10):2133-41.

24. Jain A, Njoku DB, Sponseller PD. Does patient diagnosis predict blood loss during posterior spinal fusion in children? Spine (Phila Pa 1976). 2012;37(19):1683-7.

25. Yu X, Xiao H, Wang R, Huang Y. Prediction of massive blood loss in scoliosis surgery from preoperative variables. Spine (Phila Pa 1976). 2013;38(4):350-5

26. Halanski MA, Cassidy JA. Do multilevel Ponte osteotomies in thoracic idiopathic scoliosis surgery improve curve correction and restore thoracic kyphosis? J Spinal Disord Tech. 2013;26(5):252-5.

27. Thompson ME, Kohring JM, McFann K, McNair B, Hansen JK, Miller NH. Predicting excessive hemorrhage in adolescent idiopathic scoliosis patients undergoing posterior spinal instrumentation and fusion. Spine J. 2013;14(8):1392-8.

28. Larson AN, Santos ER, Polly DW Jr., 3 Ledonio CG, Sembrano JN, Mielke $\mathrm{CH}$, et al. Pediatric pedicle screw placement using intraoperative computed tomography and 3- dimensional image-guided navigation. Spine (Phila Pa 1976). 2012;37(3):E188-94 